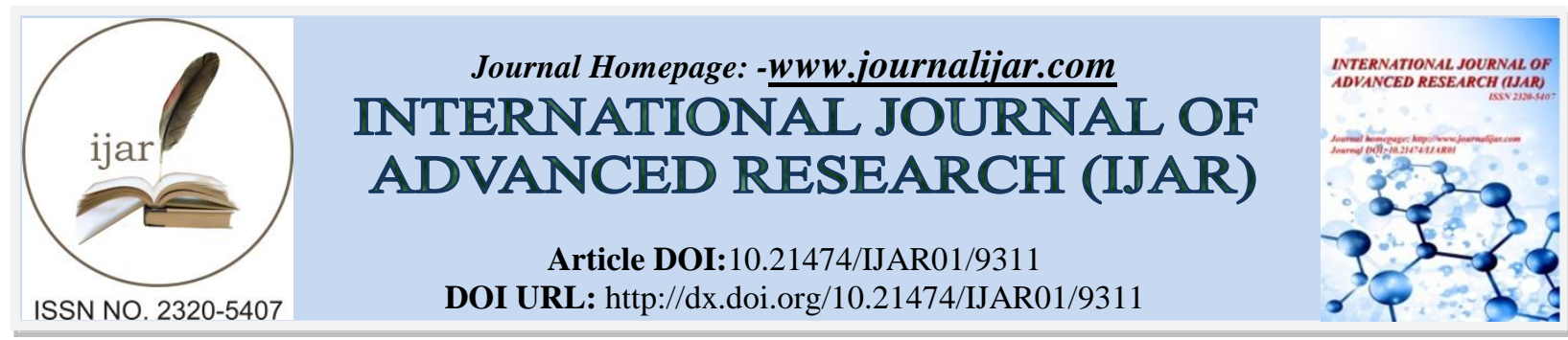

RESEARCH ARTICLE

\title{
SOCIO-ECONOMIC AND PRODUCTION CHARACTERISTICS OF PACIFIC WHITE SHRIMP, LITOPENAEUS VANNAMEI (BOONE, 1931) CULTURE IN PURBA MEDINIPUR, WEST BENGAL, INDIA.
}

\section{Anupam Maiti ${ }^{1}$, Deep Sankar Chini ${ }^{1}$, Manojit Bhattacharya ${ }^{1}$, Avijit kar ${ }^{1}$, Amalesh Bera ${ }^{1}$, Tapas Kumar Dutta $^{2}$, Utpal Kumar Sar ${ }^{3}$ and Bidhan Chandra Patra ${ }^{1}$.}

1. Centre for Aquaculture Research, Extension and Livelihood, Department of Aquaculture Management and Technology, Vidyasagar University, Midnapore, West Bengal 721 102, India.

2. Department of Zoology, Bankura Sammilani College, Bankura, West Bengal 722102, India.

3. Directorate of Fisheries, Port Blair, Andaman and Nicobar Administration, India.

\section{Manuscript Info}

Manuscript History

Received: 15 April 2019

Final Accepted: 17 May 2019

Published: June 2019

\section{Key words:-}

Brackish Water Farming, Litopenaeus vannamei, Socio-economic status, Livelihood, Fisher-folk community.

\begin{abstract}
Litopenaeus vannamei was introduced as an exotic species recommended by Coastal Aquaculture Authority of India (CAAI) in the 2003 and adopted by the progressive fish farmers applying low saline water in semi-intensive practice of culture from 2009-2010. Among the potential states of India $L$. vannamei culture is going on successfully in the coastal and brackish water enriched regions of West Bengal, particularly Purba Medinipur District. The study on the socioeconomic status and livelihood of fisher-folk community associated with brackish water farming at Purba Medinipur was conducted through interviews, group discussion, surveying with questionnaires, Participatory Rural Appraisal (PRA). The feedbacks of 500 respondents were recorded during culture periods i.e. from February to October, 2015 and in the year 2016 for the same periods. Due to various reasons they replaced Tiger Shrimp (Penaeus monodon) and shifted to culture of this exotic shrimps fetching more productivity as well as profit in respect to same unit area. With less knowledge of technology this culture is expanding vary rapidly with the guidance of multinational companies and other field level stakeholders. The major constrains were availability of good quality of certified seeds, feeds \& fertilizers, modern technology for farming, disease diagnosis centers, unregulated marketing systems and intervention of middleman, addiction etc. Proper training, scientific management, sufficient financial support by Government, infrastructural development for framing and implementation of problem soothing rules at field level can help to increase the production which in turn uplift the socio-economic status of the respective people.
\end{abstract}

Copy Right, IJAR, 2019,. All rights reserved.
Corresponding Author:-Anupam Maiti.

Address:-Centre for Aquaculture Research, Extension and Livelihood, Department of Aquaculture Management and Technology, Vidyasagar University, Midnapore, West Bengal 721 102, India. 


\section{Introduction:-}

Crustacean aquaculture has been grown up very rapidly in last few years where its annual production reached about 5 million tons in the year of 2006 (Jaspe, Caipang et al. 2011). Penaeid shrimps are the preferred crustaceans in aquaculture and vast area are invested for shrimp farming (Karuppasamy and Mathivanan 2013) because of high demand of it all over the world. India ranks second in comparison to China in shrimp production (Ravuru and Mude 2014). The recent trend shows a considerable increase of farming of $L$. vannamei replacing $P$. monodon culture due to their high growth rate, short culture duration and higher resistance to diseases (Seidman and Lawrence, 1985). As per supplied data of District Agriculture Department, Purba Medinipur District, Government of West Bengal and local information, within last few years, the single cropped hectors after hectors paddy land of coastal region of this District have converted to brackish water tank for shrimp farming to gain high profit (Patra, Mishra et al. 2016).

Declining trends of employment in government and private sectors coupled with less income from agricultural crops has forced the unemployed youth to brackish water farming. The objectives of the study were to assess the socioeconomical status of fisher-folk community and production characteristics of L. vannamei culture ultimately the profit which influences the life style, health consciousness and others. This study will help to formulate the policies and its implementation by appropriate extension, intervention to cope up with the present field level constraints, standardization of the optimum sustainable culture /management protocol.

\section{Material and methods:-}

\section{Study Area:}

The study was conducted in four sub-divisions, viz. Contai, Egra, Tamluk and Haldia in the Purba Medinipur District of West Bengal, India, which is located in between $21^{\circ} 91^{\prime} 29^{\prime \prime} \mathrm{N}$ to $22^{0} 18^{\prime} 65^{\prime \prime} \mathrm{N}$ latitude and $87^{0} 76^{\prime} 33^{\prime \prime} \mathrm{E}$ to $87^{0} 83 ' 37^{\prime \prime E ~ l o n g i t u d e . ~ B e f o r e ~ s t a r t i n g ~ t h e ~ s u r v e y ~ t o t a l ~ s t u d y ~ a r e a s ~ a r e ~ d i v i d e d ~ i n t o ~ f o u r ~ z o n e s ~ a s ~ p e r ~ s u b-d i v i s i o n ~ o f ~}$ this District up to the Community Development Block level.

\section{Variables and their measurement:}

For complete study the main twenty eight parameters were identified. Among the major techno-managerial variables such as culture area, stocking, inputs used, production and income were calculated based on water spread area. Net profit was calculated on total farm area. One cycle represents the periods from pond preparation to final harvest and drainage out of pond water. All the variables are calculated for a cycle period.

\section{Data collection:}

The tools and techniques followed by semi-structured interview and documents review (Goswami et al.1994; Shiyani and Pandya 1998); questionnaire survey, focus group discussion (Holloway 1997) and Participatory Rural Appraisal (Chambers 1992; Conway 1987) were used to get the complete information from the people who are involved with L.vannamei culture. Such types of tools were also adopted by Ghosh et al, 2015 who applied these at same state for fresh water prawn production. The questionnaires were prepared in local language i.e. Bengali and then it is translated into English and tabulated at the appropriate column. The techno-managerial parameters were studied at weekly basis at the farms of the some focused groups during this period.

The present study was carried out for a period of eight to nine months per year for consecutive two years for better accuracy of the results. The socio-economic condition and life style are directly related with the income of the farmers, and the income varies on different issues. The study was mainly conducted during culture periods i.e. from February to October, 2015 and in the year 2016 for the same periods. The primary data regarding various aspects of socio-economic condition of fisher folk community who were involved in this trade both permanently and partially were collected considering their primary income source and secondary income source respectively. In this study open-ended questions derived the answers from area of farm, amount of feed, seed, fertilizer, minerals, Probiotics used, production, harvested weight of animals and selling rates which are essential for deriving production cost and profit. During study some important photo graphs and videos were taken which are closely associated with the study. Some important advices were given to them when they faced the emergency technical problem and tested the important soil and water parameters of farms regarding their culture. In this way confidence were built up to make easy to get their information regarding their profit or loss and others. 


\section{Result and Discussions:-}

Some of the major determinants influence the socio-economic status and life style of the fisher folk community directly or indirectly. The interview schedule which acts as the tool to measure the composition of the determinants. Then the obtained result are analyzed and discussed here one by one to make final conclusion of the study.

\section{Livelihood Activities:}

The respondent i.e. brackish water fishermen are basically the paddy cultivator but due to lower percentage of return they shifted to this high risk farming. Majority (60\%) of owner respondents have taken the land from agricultural cultivators as lease @ Rs. 50,000.00 to Rs. 60,000.00/acre/year and excavated the individual tanks of area in between 100 decimal to 125 decimal per tank. Though for their livelihood hundred percentage of farmer go for one time Aman (July to October) paddy cultivation and very few (10\%) of Rabi cultivation (December to March).

The final numbers of respondent are 500 out of which $99 \%$ are male and rest are female. Majority are engaged as employee of farm $(51.00 \%)$ followed by owner of farm (46.00\%), very few as owner of farm-cum retailer of inputs $(2.20 \%) \&$ owner of farm -cum Adhatdar (local buyer i.e. 0.80\%) [Table - 1]. In this regard it is to be mentioned that around $60 \%$ of the present interviewers are being owner of farm have started this profession as employee to other's farm. And after few years of experience they have started their own business either at their own land or taking lease from others.

During the study period it was found that $87 \%$ are L.vannamei , 5.6\% are Tiger shrimp and rest $7.4 \%$ are of both species (Table-01).The experience of farming in between 4 to 14 years has replied the majority $(78.00 \%)$ of people where as very few $(0.4 \%)$ of above 14 years. The maximum numbers of people are of medium experienced category comprising middle aged group i.e. 31 to 50 years. The brackish water shrimp farming needs day night management practice and night management is more crucial as the shrimp is nocturnal in habit. As the farmers undergoes semiintensive farming, so they require to feed the P. monodon for four times daily (6am, $10 \mathrm{am}, 6 \mathrm{pm} \mathrm{\&} 10 \mathrm{pm}$ ) and aeration just before feeding for 30-40 minutes as initial stage and up to one hour for advance stage for total culture period of 125-135 days and maintain the check tray after 35 days of stocking to till harvest.

On the other hand, for L. vannamei feeding requires five times daily (6am, 10am, 3pm, $7 \mathrm{pm} \& 11 \mathrm{pm}$ ) and aeration just before feeding for 30-40 minutes as initial stage and one hour or even more for advance stage during total culture period of 95-105 days. Moreover, it is urgent to maintain the check tray after 35 days of stocking to till harvest. So, in contrast to $P$. monodon daily fishing efforts is more than $L$. vannamei. The employees must have stay at the farm throughout the day \& night with periodical interval. It is found that $86.20 \%$ of respondents have to engage around $14 \mathrm{hrs}$ followed by $10.80 \%$ for $10 \mathrm{hrs} \&$ very few $(03 \%)$ for around $6 \mathrm{hrs}$. The large farm owners engage labour for broadcasting of feed, maintaining check tray, operating pump etc. and manager for accounts related matter, maintaining log book, calculating amount of feed required for each meal and check tray (Table-01).

For the transportation of farming inputs the Table-01 represent the clear picture of the studied respondents. The majority (39.4\%) of respondent use two wheelers followed by rickshaw fitted with engine (30.2\%) and other means are comparatively with less percentage.

Table 01:-Livelihood status of L. vannamei fishermen, Purba Medinipur, West Bengal. (Respondents=500nos.)

\begin{tabular}{|l|l|l|l|l|}
\hline $\begin{array}{l}\text { S. } \\
\text { No. }\end{array}$ & Major determinants & Category details & Numbers & Measures (\%) \\
\hline \multirow{3}{*}{1.} & \multirow{2}{*}{ Mode of activities } & Owner of farm-cum Aratdar(local buyer) & 4 & 0.8 \\
\cline { 3 - 5 } & & Owner of farm-cum retailer of inputs & 11 & 2.2 \\
\cline { 3 - 5 } & & Owner of farms & 230 & 46 \\
\cline { 3 - 5 } & Employee of farm & 255 & 51 \\
\hline \multirow{2}{*}{$\begin{array}{l}\text { Type of species } \\
\text { cultivated }\end{array}$} & (a) Mexican white shrimp( L.vannamei) & 435 & 87 \\
\cline { 3 - 5 } & & (b) Tiger Shrimp(P. monodon) & 28 & 5.6 \\
\cline { 3 - 5 } & () both Mexican White shrimp \& Tiger shrimp & 37 & 7.4 \\
\hline 3. & Experience of farming & Up to 4 years & 108 & 21.6 \\
\cline { 3 - 5 } & & 4 years to 14 years & 390 & 78 \\
\cline { 3 - 5 } & & above 14 years & 2 & 0.4 \\
\hline 4. & Daily fishing efforts & $\geq 06$ hrs./day & 15 & 3 \\
\hline
\end{tabular}




\begin{tabular}{|l|l|l|l|l|}
\hline & 10 hrs./day & 54 & 10.8 \\
\cline { 3 - 5 } & \multirow{3}{*}{5.} & $\leq 14$ hrs./day & 431 & 86.2 \\
\cline { 3 - 5 } & Means of transport & (a) Bicycle & 38 & 7.6 \\
\cline { 3 - 5 } & (b)Two wheelers & 197 & 39.4 \\
\cline { 3 - 5 } & (c) Rickshaw & 45 & 9 \\
\cline { 3 - 4 } & (d) Rickshaw fitted with engine & 151 & 30.2 \\
\cline { 3 - 4 } & (e) Small four wheeler including above & 69 & 13.8 \\
\hline
\end{tabular}

\section{Economic Status:}

In order to measure the economical status of each family depending on L.vannamei farming, criteria likecultivated area, annual income, total investment,marketing and credit system are considered as key determinants. In respect to total farm area or cultivated area, Haldia Sub-division ranked first among the four Sub-divisions. In Contai subdivision the large number of farmers are involved with less total farm area ranging from 1 acre to 2.5 acre. The observed result depicted that $77.60 \%$ farmer posses area in between 01 acre to 05 acres, $16 \%$ farmer up to 01 acre and $6.40 \%$ farmer above 05 acres [Table-02].

Besides, such types of fish farming everybody mandatorily cultivate paddy, horticultural crop \& even fresh water fish, except a few families prefer cattle and chicken rearing. During lean period the labour or small farmer went to the different states for temporary works. That's why their total annual family income includes the above. Though their income directly depends upon the amount of production as well as demands and rate at the international markets.

The lowest incomes groups of up to Rs. $1,00,000.00$ constitute to $22.40 \%$ are mainly employees. Managers and small sized farmers (area up to 1acres) are mainly of lower middle income group (49.4\%) of Rs. 1, 00,001.00 to Rs.2, 00,000.00. The medium sized farmers (area above1acre to 05 acres) of $17.6 \%$ are of upper middle income groups of Rs. 2, 00,001.00 to Rs.3, 00,000.00. Lastly the big farmers ( area above 05 acre / farmer-cum retailers / farmer-cum buyer are the highest income group (10.6\%) whose income is in between Rs.3,00,001.00 to Rs.400000.00 [Table-02]. About 75-80\% of owners earn the above mentioned amount but others losses due to early mortality of $L$. vannamei and fall of international demands. This problem does not affect the employees.

This trade requires higher amount of funding per unit area( Rs. 2,50,000.00 -Rs.2,60,000.00 /crop/acre for $L$. vannamei and Rs. 2,80,000.00 -Rs.3,00,000.00/crop/acre for tiger shrimp). So, most of the farmers (64.20\%) depends on both inputs retailers and money lenders whereas $33.60 \%$ fully depends on inputs retailers. These types of respondents bound to repay their credit to the retailers as per the MRP and to the money lenders with interest which are 3 to 4 times higher than the financial institution. So retailers and money lenders are much gainer than that of other. Sometimes retailers forced to sell the crop through their selected local buyers for repayment of their loan. So in brief it can be concluded that the growers are always in the grip of octopus like retailers [Table-02].

The other scenario concerns, purchasing of feed, aqua-medicines and others by cash is more profitable than other means as cash purchase gives concession on MRP of around 5\% to $10 \%$ on feed and even up to $25 \%-30 \%$ on aqua-medicines. In earlier discussion we have seen that middleman mainly retailers and buyers is the main controller of this trade. About $89.40 \%$ respondents opined that middlemen are involved highly by means of pond preparation to sell of product. At every steps of culture technical knowledge about the new species is very much essential for higher production and prevention of diseases. Respondents reply that marketing of this type of crop at any weight is totally controlled by the 10-15 numbers of major buyers throughout the district. The producer bound to sell their crop to them after little bit bargaining. The buyers after taking crop from farmers they maintain post harvest techniques to avoid any deterioration of quality. The buyers directly sell the harvested crop to processing plants as per gradation system. Then the foreign exporters purchased from processors. This is a brief account of the said crop marketing system.

After receiving the value of crops $88.6 \%$ does not keep it safe rather they expend it for purchasing motor bike, land, ornaments, maintaining house, rituals, nourishment, education etc. Few person $(11.4 \%)$ can deposit the money at any bank for future investment [Table -2$]$.

Table 02:- Economic status of brackish water fishermen, Purba Medinipur, West Bengal. (Respondents=500nos.)

\begin{tabular}{|l|l|l|l|l|}
$\mathrm{Sl}$ & Major determinants & Category details & Numbers & Measures $(\%)$ \\
\hline
\end{tabular}




\begin{tabular}{|c|c|c|c|c|}
\hline \multicolumn{5}{|c|}{ No } \\
\hline \multirow[t]{3}{*}{1.} & \multirow[t]{3}{*}{ Area of farm(s) } & up to 01 acre(small) & 80 & 16 \\
\hline & & Above 01 acre to below 05 acre(Medium) & 388 & 77.6 \\
\hline & & Above 05 acres(Big) & 32 & 6.4 \\
\hline \multirow[t]{4}{*}{2.} & \multirow[t]{4}{*}{ Annual family income } & Lowest income group(up to Rs.100000.00) & 112 & 22.4 \\
\hline & & $\begin{array}{lll}\text { Lower middle income } & \text { group(Rs.100001.00- } \\
\text { Rs.200000.00) } & & \\
\end{array}$ & 247 & 49.4 \\
\hline & & $\begin{array}{lll}\text { Upper middle } & \text { income } & \text { group(Rs.200001.00- } \\
\text { Rs.300000.00) } & & \end{array}$ & 88 & 17.6 \\
\hline & & $\begin{array}{l}\text { Highest income group(Rs.300001.00- } \\
\text { Rs.400000.00) }\end{array}$ & 53 & 10.6 \\
\hline \multirow[t]{4}{*}{3.} & \multirow[t]{4}{*}{ Credit system } & (a) Own fund & 7 & 1.4 \\
\hline & & (b) Financial Institutions & 4 & 0.8 \\
\hline & & (CFully depends on inputs retailers & 168 & 33.6 \\
\hline & & (d) Depends on inputs retailer \& money lenders & 321 & 64.2 \\
\hline \multirow[t]{3}{*}{4.} & \multirow{3}{*}{$\begin{array}{l}\text { Middlemen's } \\
\text { Involvement }\end{array}$} & (a) Low & 4 & 0.8 \\
\hline & & (b) Moderate & 49 & 9.8 \\
\hline & & (c) High & 447 & 89.4 \\
\hline 5. & Marketing system & Selling to local buyers & 500 & 100 \\
\hline \multirow[t]{2}{*}{6.} & \multirow[t]{2}{*}{ Saving system } & (a) Does not save for future at financial institution & 443 & 88.6 \\
\hline & & (b) Save at Banks & 57 & 11.4 \\
\hline
\end{tabular}

\section{Social Status:}

Pollobi Kalita and Parag Deka(2015) classified the age of fishermen into four groups as young aged (21-30 years), early middle aged (31-40 years), late middle aged(41-50 years) and old(51-60 years or above) and majority are in the range between $41-50$ years $(37.50 \%)$ and the least is in between51-60 years or more $(12.50 \%)$ around the landing sites of Tinsukia District of Assam, India. It has similarities with this results where young aged (21-30 years) are $33.60 \%$, early middle aged (31-40years) $42.80 \%$, late middle aged (41-50 years) $17.80 \%$ and old aged (51-60 years or above) $5.80 \%$ [Table-03].

It is proud to say that this district stands regularly first for last few years for the highest percentage of pass out at Class X standard under West Bengal Board of Secondary Education. And the results showed at the Table-03 also have the similarity with the above statement. Among the respondents majority $(76.6 \%)$ are in between Class VI to XII pass followed by $12.6 \%$ graduate $\&$ above. Consistent with these studies, no person was found as illiterate. In the educational point of view, $97.2 \%$ respondents send their child to the locally situated government schools \& benefitted by government project like ICDS for nursery stages, Mid Day Meal, bi-cycle as "Sabuj Sathi" for Class IX \& X, school dress, books and scholarship for SC \& ST students. Even drop out is not found among the girl child. It may be due to the financial assistance of government through the famous project "kanyashree" to unmarried girls who will be eligible for Rs. 25,000.00 if they continue study and family income is less than Rs. 1, 20,000.00 / year

Search of income forced the youth to enter into this profession rather than the caste oriented profession. The result found from the respondents that $23.60 \%$ of Scheduled Caste (SC), $64.8 \%$ of General Caste (GC) \& rest are Other Backward Class (OBC-A \& B). Out of total SC only 35.59\% are of fishermen by caste others are of different (Table-03). Halder, Bhaumik and Pandit (1998) estimated that majority of fishermen belong to SC in villages of West Bengal.

During study period medium sized family with 06 to 08 members is highest in percentage (80.80\%) in comparison to small sized family $(16.80 \%)$ and big sized family $(2.40 \%)$. Similar type of observation was also reported by Kalita and Deka, (2015).

Majority of respondents $(97.80 \%)$ have maintained proper age of marriage while rest undergone child marriage especially in case of girls. Due to positive impact of education these societies have no strictness as well as conservativeness about inter caste marriage, but they generally prefer marriage between same castes. The respondent (97.40\%) replied that they do not accept dowry in terms of cash but they do not refuse the gifts from bridal side. The result shows that $94.6 \%$ of the participants watch TV for news, movies, popular evening programme and 5.4\% 
respondents read news paper. Among the respondents $9.60 \%$ are directly involved at the politics whereas $38.60 \%$ are involved indirectly. The rests have no interest except casting their vote [Table-03].

Table 03:-Social status of brackish water fishermen, Purba Medinipur, West Bengal. (Respondents=500nos.)

\begin{tabular}{|c|c|c|c|c|c|c|c|}
\hline $\begin{array}{l}\text { Sl } \\
\text { No }\end{array}$ & $\begin{array}{l}\text { Major } \\
\text { Determinants }\end{array}$ & Category details & Numbers & $\begin{array}{l}\text { Measures } \\
(\%)\end{array}$ & $\begin{array}{l}\text { Sub-Category } \\
\text { details }\end{array}$ & Numbers & Measures(\%) \\
\hline \multirow[t]{4}{*}{1.} & \multirow{4}{*}{ Age Group } & Young aged( $21-30$ years $)$ & 168 & 33.6 & & & \\
\hline & & $\begin{array}{l}\text { Early middle aged(31-40 } \\
\text { years) }\end{array}$ & 214 & 42.8 & & & \\
\hline & & $\begin{array}{l}\text { Late middle aged(41-50 } \\
\text { years) }\end{array}$ & 89 & 17.8 & & & \\
\hline & & $\begin{array}{l}\text { Old aged(51 -60 years or } \\
\text { above) }\end{array}$ & 29 & 5.8 & & & \\
\hline \multirow[t]{2}{*}{2.} & \multirow[t]{2}{*}{ Marriage } & (a) Adult marriage & 489 & 97.8 & & & \\
\hline & & (b) Early Marriage & 11 & 2.2 & & & \\
\hline \multirow[t]{2}{*}{3.} & \multirow{2}{*}{$\begin{array}{l}\text { Dowry } \\
\text { system }\end{array}$} & (a) Takes in kinds & 487 & 97.4 & & & \\
\hline & & (b) Without any dowry & 13 & 2.6 & & & \\
\hline \multirow[t]{3}{*}{4.} & \multirow[t]{3}{*}{ Family size } & $\begin{array}{l}\text { Small } \\
\text { members })\end{array} \quad$ family $(\leq 5$ & 84 & 16.8 & & & \\
\hline & & $\begin{array}{l}\text { Medium family(6 to } 8 \\
\text { members) }\end{array}$ & 404 & 80.8 & & & \\
\hline & & $\begin{array}{ll}\text { Large } & \text { family }(\geq 9 \\
\text { members }) & \end{array}$ & 12 & 2.4 & & & \\
\hline \multirow[t]{3}{*}{5.} & \multirow[t]{3}{*}{ Education } & (a) Up to class V & 54 & 10.8 & & & \\
\hline & & (b) Class VI to XII & 383 & 76.6 & & & \\
\hline & & (c) Graduate and Above & 63 & 12.6 & & & \\
\hline \multirow[t]{2}{*}{6.} & \multirow{2}{*}{$\begin{array}{l}\text { Preference of } \\
\text { educational } \\
\text { institute }\end{array}$} & $\begin{array}{l}\text { (a) Prefer local Govt. } \\
\text { aided school for child }\end{array}$ & 486 & 97.2 & & & \\
\hline & & (b) Prefer private school & 14 & 2.8 & & & \\
\hline \multirow[t]{4}{*}{7.} & \multirow[t]{4}{*}{ Caste } & \multirow[t]{2}{*}{ (a) $\mathrm{SC}$} & \multirow[t]{2}{*}{118} & \multirow[t]{2}{*}{23.6} & $\begin{array}{l}\text { (i) Fishermen } \\
\text { By Caste }\end{array}$ & 42 & 35.59 \\
\hline & & & & & $\begin{array}{l}\text { (ii) Caste of } \\
\text { other } \\
\text { profession }\end{array}$ & 76 & 64.41 \\
\hline & & (b)GC & 324 & 64.8 & & & \\
\hline & & (c) $\mathrm{OBC}(\mathrm{A}+\mathrm{B})$ & 58 & 11.6 & & & \\
\hline \multirow[t]{4}{*}{8.} & \multirow{4}{*}{$\begin{array}{l}\text { Social } \\
\text { participation }\end{array}$} & \multirow{2}{*}{$\begin{array}{l}\text { (a) Watching TV for } \\
\text { news, movies, popular } \\
\text { evening programme }\end{array}$} & \multirow[t]{2}{*}{473} & \multirow[t]{2}{*}{94.6} & (i) Regular & 196 & 41.44 \\
\hline & & & & & $\begin{array}{l}\text { (ii) } \\
\text { Occasional }\end{array}$ & 277 & 58.56 \\
\hline & & \multirow[t]{2}{*}{ (b)Reading news paper } & \multirow[t]{2}{*}{27} & \multirow[t]{2}{*}{5.4} & (i) Regular & 8 & 29.63 \\
\hline & & & & & $\begin{array}{l}\text { (ii) } \\
\text { Occasional }\end{array}$ & 19 & 70.37 \\
\hline \multirow[t]{3}{*}{9.} & \multirow{3}{*}{$\begin{array}{l}\text { Involvement } \\
\text { in Politics }\end{array}$} & (a) Directly involved & 48 & 9.6 & & & \\
\hline & & (b)Indirectly involved & 193 & 38.6 & & & \\
\hline & & $\begin{array}{l}\text { (1) Not direct \& indirect } \\
\text { only cast vote }\end{array}$ & 259 & 51.8 & & & \\
\hline
\end{tabular}

\section{Pattern of Lifestyle}

In connection with entertainment, addiction, house pattern, cell phone and internet using are the key determinant to dictate the pattern of life style. Playing cards (75.4\%), satta and gossiping in groups at local teashop premises are the means of common entertainment. They are addicted with any one of the addition for liquor, smoking of tobacco \& chewing of betel leaves (97.8 \%). During survey it is found that $41.4 \%$ of the respondents lives in the 'pukka' house rest are earthen. And both the State Government and Central Government have the close monitoring for the poor and needy for constructing their pukka house by different schemes like Gitanjali, Amar Bari, and Indira Awas Yojana/PMAY etc. with $100 \%$ electricity connection. The $100 \%$ household founds main electrical equipments such 
as light, fan, TV and very few 1-2\% found freeze. All the respondents (100\%) use mobile among them 17.60\% having the connectivity of internet and participate in socialmedia. (Table-04)

Table 04:-Pattern of Life style of brackish water fishermen, Purba Medinipur, West Bengal. (Respondents=500nos.)

\begin{tabular}{|c|c|c|c|c|c|c|c|}
\hline $\begin{array}{l}\text { Sl } \\
\text { No }\end{array}$ & $\begin{array}{l}\text { Major } \\
\text { determinants }\end{array}$ & Category details & Numbers & $\begin{array}{l}\text { Measures } \\
(\%)\end{array}$ & $\begin{array}{l}\text { Sub-Category } \\
\text { details }\end{array}$ & Numbers & $\begin{array}{l}\text { Measures } \\
(\%)\end{array}$ \\
\hline \multirow[t]{3}{*}{1.} & \multirow{3}{*}{$\begin{array}{l}\text { Means of } \\
\text { entertainment }\end{array}$} & (a) Only playing cards & 377 & 75.4 & & & \\
\hline & & $\begin{array}{l}\text { (b) Playing cards \& } \\
\text { satta }\end{array}$ & 118 & 23.6 & & & \\
\hline & & (c) Nothing above & 5 & 1 & & & \\
\hline \multirow[t]{4}{*}{2.} & \multirow[t]{4}{*}{ Addiction to } & $\begin{array}{l}\text { (a)Chewing of betel } \\
\text { leaves \& smoking }\end{array}$ & 362 & 72.4 & & & \\
\hline & & \multirow{2}{*}{$\begin{array}{l}\text { (b)Chewing of betel } \\
\text { leaves, smoking and } \\
\text { drinking liquor }\end{array}$} & \multirow[t]{2}{*}{127} & \multirow[t]{2}{*}{25.4} & (i) Regular & 45 & 35.43 \\
\hline & & & & & (ii) Occasional & 82 & 64.57 \\
\hline & & (c) Nothing above & 11 & 2.2 & & & \\
\hline \multirow[t]{4}{*}{3.} & \multirow[t]{4}{*}{$\begin{array}{l}\text { Housing } \\
\text { Pattern }\end{array}$} & \multirow[t]{2}{*}{ (a) Pukka } & \multirow[t]{2}{*}{207} & \multirow[t]{2}{*}{41.4} & $\begin{array}{ll}\text { (i) } & \text { Asbestos } \\
\text { roofing } & \end{array}$ & 137 & 66.18 \\
\hline & & & & & $\begin{array}{ll}\text { (ii) } & \text { Concrete } \\
\text { roofing } & \\
\end{array}$ & 70 & 33.82 \\
\hline & & \multirow[t]{2}{*}{ (b) Earthen } & \multirow[t]{2}{*}{293} & \multirow[t]{2}{*}{58.6} & $\begin{array}{l}\text { (i) with straw } \\
\text { roofing }\end{array}$ & 73 & 24.91 \\
\hline & & & & & $\begin{array}{l}\text { (ii) Burned earthen } \\
\text { tiles }\end{array}$ & 220 & 75.09 \\
\hline \multirow[t]{2}{*}{4.} & \multirow{2}{*}{$\begin{array}{l}\text { Mobile } \\
\text { Internet } \\
\text { using pattern }\end{array}$} & \multirow[t]{2}{*}{ (a) Mobile users } & \multirow[t]{2}{*}{500} & \multirow[t]{2}{*}{100} & $\begin{array}{l}\text { (i)Only mobile } \\
\text { without internet }\end{array}$ & 412 & 82.40 \\
\hline & & & & & $\begin{array}{l}\text { (ii) Smart phone } \\
\text { with internet\& } \\
\text { social net works } \\
\text { users }\end{array}$ & 88 & 17.60 \\
\hline
\end{tabular}

\section{Health Cautiousness}

The District authority have closed surveillance on sanitation facility as this is the open defecation free District and have good steps for $100 \%$ toilet \& latrine but very few (4.32\%) have bath room mainly for women. This is also second another point where all respondents found aware about family planning $58.8 \%$ found single child \& rest $41.2 \%$ are of two children. All the respondent replies that they have maintain very good nutritional food for families. Everybody prefers non vegetable meals mainly fresh, brackish as well as marine water fish and eggs as per availability. Even they (63.2\% respondents) take chickens for fortnightly while $31.4 \%$ weekly and rests are occasionally. Besides, they prefer seasonal fruits and vegetables to fulfill their nourishment. As a result majority of families (99.00\%) does not have malnourished members mainly child. It is also investigated that respondents $(91.20 \%)$ have no critical disease except few like high blood pressures, sugar. It is because of better nutritional intake, hard working \& better life style [Table-05].

Table 05:-Health cautiousness of brackish water fishermen, Purba Medinipur, West Bengal. (Respondents=500nos.)

\begin{tabular}{|c|c|c|c|c|c|c|c|}
\hline $\begin{array}{l}\text { Sl } \\
\text { No }\end{array}$ & $\begin{array}{l}\text { Major } \\
\text { determinants }\end{array}$ & Category details & Numbers & $\begin{array}{l}\text { Measures } \\
(\%)\end{array}$ & Sub-Category details & Numbers & $\begin{array}{l}\text { Measures } \\
(\%)\end{array}$ \\
\hline \multirow[t]{2}{*}{1.} & \multirow{2}{*}{$\begin{array}{l}\text { Sanitary } \\
\text { facility }\end{array}$} & \multirow{2}{*}{$\begin{array}{l}\text { Having toilet \& } \\
\text { latrine }\end{array}$} & \multirow[t]{2}{*}{500} & \multirow[t]{2}{*}{100} & (i) Having bathroom & 22 & 4.40 \\
\hline & & & & & (ii) Without bath room & 478 & 95.60 \\
\hline \multirow[t]{2}{*}{2.} & \multirow{2}{*}{$\begin{array}{l}\text { Family } \\
\text { Planning }\end{array}$} & \multirow{2}{*}{$\begin{array}{l}\text { Planed by both } \\
\text { husband and wife }\end{array}$} & \multirow[t]{2}{*}{500} & \multirow[t]{2}{*}{100} & (i) Single child family & 294 & 58.80 \\
\hline & & & & & (i) Two children family & 206 & 41.20 \\
\hline \multirow[t]{3}{*}{3.} & \multirow[t]{3}{*}{$\begin{array}{l}\text { Nutritional } \\
\text { Fulfillment }\end{array}$} & \multirow[t]{3}{*}{$\begin{array}{l}\text { (a) Non vegetable } \\
\text { diet with fish/egg }\end{array}$} & \multirow[t]{3}{*}{500} & \multirow[t]{3}{*}{100} & $\begin{array}{l}\text { a. (i) Fish / Eggs almost } \\
\text { every day }\end{array}$ & 96 & 19.20 \\
\hline & & & & & $\begin{array}{l}\text { a. (ii) Fish / Eggs for 4-5 } \\
\text { days/week }\end{array}$ & 281 & 56.20 \\
\hline & & & & & a. (iii) Fish / Eggs when & 123 & 24.60 \\
\hline
\end{tabular}




\begin{tabular}{|c|c|c|c|c|c|c|c|}
\hline & & & & & available & & \\
\hline & & $\begin{array}{l}\text { (a) Non vegetable } \\
\text { diet with meat }\end{array}$ & & & $\begin{array}{ll}\text { a.(1) Meat for } \\
\text { fortnightly }\end{array}$ & 316 & 63.20 \\
\hline & & & & & a.(2) Meat for weekly & 157 & 31.40 \\
\hline & & & & & a.(3) Meat for occasion & 27 & 5.40 \\
\hline 4. & $\begin{array}{l}\text { Health } \\
\text { status }\end{array}$ & $\begin{array}{l}\text { Does } \\
\text { much }\end{array}$ not $\begin{array}{r}\text { have } \\
\text { critical }\end{array}$ & 456 & 91.2 & $\begin{array}{l}\text { (i) Prefer Government } \\
\text { Hospitals }\end{array}$ & 45 & 9.87 \\
\hline & medical & disease & & & (ii) Prefer private doctor & 411 & 90.13 \\
\hline & $\begin{array}{l}\text { facility } \\
\text { availed }\end{array}$ & $\begin{array}{l}\text { Having critical } \\
\text { diseases (like heart, }\end{array}$ & 44 & 8.8 & $\begin{array}{l}\text { (i) Prefer Government } \\
\text { Hospitals }\end{array}$ & 5 & 11.36 \\
\hline & & $\begin{array}{l}\text { kidney, liver, } \\
\text { gastro) }\end{array}$ & & & (ii) Prefer private doctor & 39 & 88.64 \\
\hline
\end{tabular}

\section{Conclusions:-}

The studies clearly indicate that various problems of farmers can be solved with the help of field level stakeholders if they emphasize on concerned people's livelihood. Furthermore, resources like human, water, land can be utilized in a sustainable ways for better improvement of socio-economic status and livelihood of fisher folk community associated with brackish water farming at Purba Medinipur, West Bengal. All farmers raised their demands and also the researchers have the same view after minute observation i.e. proper training about culture \& management practice of the species, disease prevention and control, availability of certified specific pathogen free (SPF) seed, control of Government on rate and quality of feed, fertilizers, medicine etc. and other necessary requirements, laboratory for soil, water and disease testing, cold storage for crop at the time of low selling rate, more involvement of financial institutes, control of Government over the intervention of middleman at every step of this system, proper infrastructure for entertainment and awareness to eradicate the deadly addiction. Enlistment in the insurance scheme like agricultural insurance to encourage and support their livelihood, upliftment of family members of the farmer is very much urgent in tune with life style, education, health progress. Consistent with this development of infrastructure in their villages is thought to be another prime factor for encompassing the socio-economy, over all development is required if the farmer can alleviate the poverty through L.vannamei culture by means of earning money.

\section{Acknowledgement: -}

We all thankful to all the respondent of Purba Medinipur District and Block level employees of Fisheries Deptt., Govt. of West Bengal for their cooperation. We also thankful to the all scholars of the Laboratory, AMT Deptt., Vidyasagar University and ultimately the respondents for their necessary help.

\section{Reference:-}

1. Chambers, R. (1992): Rural appraisal: rapid, relaxed and participatory,” IDS Discussion Paper, No. 311 Brighton: Institute of Development Studies, University of Sussex, UK, ISBN-0 903715.

2. Conway, G. (1987): Rapid rural appraisal and agro ecosystem analysis: A case study from Northern Pakistan, in KKU. Proceedings of the 198.5 International Conferences on Rapid Rural Appraisal. Systems Research and Farming Systems Research Projects (Khon Kaen, Thailand: University of Khon Kaen), pp. 228-254.

3. Ghosh, SK; Ahmmed, MK; Ahmed, SI; Ahsan, K and Kamal, M.(2015): Study on the socio-economic conditions of the fishermen in Tekhat. Res. Agric. Livest. Fish, 2(3): $483-489$.

4. Goswami, M.M.; Lahon, B; Kakati, M; Deka, T K; Sarma, P and Singha,P K. (1994): Fishery exploitation system and their impact on socio- economic status of fisher man in some beels of Assam. Journal of Inland Fisheries Societies of India, 26 (1):51-58.

5. Halder, D.P.; Bhaumik, U and Pandit, S.K.(1998): In one village of West Bengal fish mix with food. J. Indian Farming, 38(8):29.

6. Holloway, I. (1997): Basic concepts for qualitative research. London: Blackwell Science.

7. Jaspe, C. J., et al. (2011): Modified extensive pond culture of Litopenaeus vannamei for sustainable shrimp culture in the Philippines." Advances in EnvironmentalSciences 3(1).

8. Karuppasamy, A. and V. Mathivanan (2013). "Comparative Growth Analysis of Litopenaeus vannamei in Different Stocking Density at Different Farms of the Kottakudi Estuary, South East Coast of India. Int. J. Fish. Aquat. Sci. 1(2): 40-44. 
9. Kalita, P and Deka, P. (2015). Socio-Economic condition and livelihood status of fisher around the landing sites of Motapung-Maguri Beel of Tinsukia District of Assam, India. International Journal of Fisheries and Aquatic Studies , :3(2):55-57.

10. Patra, S., et al. (2016): Modelling impacts of chemical fertilizer on agricultural production: a case study on Hooghly district, West Bengal, India. Modeling Earth Systems and Environment, 2(4): 1-11.

11. Ravuru, D. B. and J. N. Mude (2014). "Effect of density on growth and production of Litopenaeus vannamei of brackish water culture system in summer season with artificial diet in Prakasam District, India." Am Int J Res Formal Appl Nat Sci 5(1): 10-13.

12. Seidman, E. R. and Lawrence, A.L.(1985): Growth, Feed Digestibility and Proximate Body Composition of Juvenile Penaeus vannamei and Penaeus monodon Grown at Different Dissolved Oxygen Levels. Journal of the World Mariculture Society ,16(1-4): 333-346.

13. Shiyani, R.L. and Pandya. H.L. (1998): Diversification of Agriculture in Gujarat: A Spatio-Temporal Analysis. Indian Journal of Agricultural Economics, 53(4): 624-639. 